\title{
Assessing the Importance of Party and Gender in Legislators' Policy Preferences
}

\section{Gregory S. Thielemann, University of Texas at Dallas}

In recent years much has been written about what factors influence the policy preferences of legislators in general and women legislators specifically. This analysis explores the relative importance of a member's sex, party, locality and tenure on policy preferences in the 71 st Texas House of Representatives with its low levels of professionalism and party influence. The members were surveyed for their views on the four most pressing issue areas they faced: education reform, judicial selection reform, workers' compensation insurance reform and abortion. Surprisingly, party is important in explaining policy preferences on education reform, judicial selection reform and workers' compensation reform. Being a woman is of less importance in these areas, but is more important in the area of abortion rights.

In recent decades, much has been written about the influences that affect legislators' policy preferences. Two factors that are often discussed are the party affiliation and sex of the legislator. The linkage between party affiliation and legislative voting has almost assumed the status of conventional wisdom, as it has been applied to Congress (Bullock and Brady 1985; Shelley 1983) and state legislatures with strong party systems (Jewell and Olson 1988). The role of a legislator's sex in influencing voting behavior has been less discussed, and represents a considerably more recent trend in the literature. This literature has focused on the role of women in the legislative process. Some of the research has concentrated on the role of women in the legislative arena, where women are considered as policymakers rather than candidates or fundraisers, while other research has focused on the problems women candidates face in public perceptions and fundraising. In general, this literature finds that women face additional difficulties in coping with public perceptions of their role in political settings. Ruth Mandel $(1981,43)$ calls this the "double bind," implying that if a woman is aggressive and assertive, she is not feminine enough; if she is not aggressive, she is too weak. In either case, the woman loses. At a more basic level, the fact that women must cope with such public concern represents an additional burden on women politicians that their male counterparts do not shoulder. In a similar way, women legislators are sometimes treated as either captives

Gregory S. Thielemann is Associate Professor of Government, Politics and Political Economy at the University of Texas at Dallas.

The American Review of Politics, Vol. 16, Summer, 1995: 151-165

(๑1995 The American Review of Politics 
of a "radical feminist agenda" or, more subtly put, inclined to champion "women's issues," which may in reality be as diverse as reproductive freedom to child care and education (Becker 1989; Diamond 1977). Although the overall importance of a legislator's gender in policy making is a matter of considerable debate in the rather robust literature that includes studies of bill sponsorship, bill passage, gender-based cohesiveness and survey data from women policymakers, there is some reason to believe that it can be an important influence on a member's policy preferences. This analysis uses recent survey data from the 71st Texas House of Representatives (19891990 ) to further explore the relative importance of a member's party and sex on legislative policy preferences.

\section{Background}

In this analysis, two bodies of literature are important: the case specific literature on Texas, and the literature on women in legislatures. To assess the role of party and sex in influencing the views of members in Texas, one must first understand the formative traits that shape policy making in the Texas House of Representatives. In addition, the existing literature on women policy makers is important because it guides the paper to gender as a potential explanatory variable.

\section{The Texas Legislature}

Although all legislative institutions will share commonalities, stark differences often present additional problems for comparative analyses of legislative behavior. These differences are traced to variations in leadership (Rosenthal 1981), committee structure (Francis and Riddlesperger 1982; Hamm and Moncrief 1982), professionalism (Jewell and Patterson 1977) and the political culture of the state (Francis 1985). In assessing the role of a member's party and sex on policy preferences, the related characteristics of the Texas legislative system are important.

In Texas, political parties have traditionally been without much structural power in the political process. Unlike states where the party system plays an important role in influencing and even limiting the way a speaker uses' power, the Texas speakers have effectively made partisanship, at least in formal procedures, inconsequential. In Texas, the speaker is elected by collecting pledge cards from any member, regardless of party affiliation. In this system, parties play no role in electing leaders or in committee assignments, which means that they have no organizational role to play. The permanent minority status of the Republicans in the House, combined with the 
presence of speakers who achieve power through personal rather than partisan relationships, has created what amounts to a non-partisan legislature with nominal Democratic leadership. Since 1975, the Speakers have routinely given members of each political party chairmanships of committees in order to reduce the importance of partisan cleavages in the chamber. ${ }^{1}$

Even at its highest level, the Republican party remains a clear minority, but in a system where the leadership desires cooperation from all members, their numbers encourage the speaker to forge non-partisan coalitions and leadership teams. Similarly, it is equally rational for minority party members to engage in this arrangement and avoid being locked out of power positions (McNeely 1989). This mutuality of interests results in the maintenance of highly centralized leadership and reduces sharp partisan divisions in the House. ${ }^{2}$ Recently, particularly on tax and finance votes, the Republicans have demonstrated a high degree of party loyalty, and journalists have been quick to report this trend (Dallas Morning News April 4, 1993). However, these votes remain the exception, as party remains a secondary influence more often than not (Thielemann and Thomas 1990).

To be certain, women face special problems in the Texas Legislature. In terms of legislative opportunity, the low levels of professionalism found in Texas' biennial legislature, with its part-time work and part-time pay, should present problems for both men and women. In Texas, it appears these factors have a greater impact on women. According to the literature, Texas is both a state where more women should be elected due to the structural artifacts of low pay $(\$ 7,200$. per year) and the relatively low prestige afforded the part-time membership (Diamond 1977), but also a state where the political culture of the South might work against women candidates (Rule 1981 and 1990).

In the 71 st Texas House (1989-1990), only 16 of the 150 members were women-slightly more than $10 \%$. While this number is small, it reflects a steady growth; 10 years earlier there were only 11 out of 150 , and 20 years earlier there was only one out of 150 . In an era when women are consistently asked to accomplish more tasks related to both work and family, a part-time, poorly paid job in the Texas Legislature may offer little appeal. It is worth noting that this pattern of representation is consistent with previous work by Darcy, Welch and Clark (1984) on the bordering state of Oklahoma, which also maintains a part-time legislature.

Additionally, the influence of the leadership and the presence of an extensive, if unspecialized, committee system present further problems for women. The lack of party influence has resulted in a non-partisan House run by "good ol' boys" of both parties that presents problems for women legislators wishing to join the inner circles of power. Although an occasional 
woman achieves power associated with chairing a committee or sitting on an influence committee, they are more commonly left out. These sentiments are best expressed by former State Representative Lena Guerrero, who lamented that there were two drawbacks to being a woman in the Texas House: the first, that she wasn't invited to go on hunting trips, which was where most of the decisions in the House were made; the second, that she couldn't go to the men's room where the remaining decisions were made (Guerrero 1990, 199). Consider that of the 58 total seats on the four influence committees ${ }^{3}$ in the 71 st Texas House, only 3 were given to women. In other words, women made up $10.6 \%$ of the House and only $5.1 \%$ of the seats on influence committees.

\section{Women as Legislators}

Although nationwide, women now account for $17.1 \%$ of all state legislators, these numbers remain small in case specific settings. This is particularly true in the South, where the region's traditional political culture has worked against the success of women legislative candidates (Main et al. 1984; Rule 1990). These small numbers make comparative studies attractive because of the greater number of cases, but such approaches require the researcher to fully understand the differences in political culture and legislative structure. The literature on women as policy makers is impressive and addresses two critical topics: the policy preferences of women and the institutional role of women in legislative settings. In each case, the stereotyping of women legislators is visible, and results from the assumption that women in policy making positions are different than their male counterparts (Mezey 1978a, 369).

On the subject of the policy preferences of women in policy-making positions, the evidence is inconclusive on the merits of using gender as an explanatory variable. Early research by Mezey $(1978 \mathrm{a}, 384)$ on the women legislators in Hawaii found that although women support the principle of other women serving in public office, they "did not demonstrate more support for policy issues that affect women in society." Carroll (1985) confirms this when she finds that women are not easily grouped by the issues they support.

In contrast, other researchers have found patterns in the policy-making behavior of women legislators. These patterns have attracted interest in the two broad areas of policy that affect women: the feminist agenda (Saint Germain 1989) and the traditional women's issues related to family issues, education and children (Diamond 1977; Becker 1989). These issues are traditionally associated with a woman's domestic concerns like children 
(Sapiro 1981) or their translation into broader public policies that impact those domestic concerns like education policy or health care (Werner 1968; Leader 1977; Darcy, Welch and Clark 1987).

In addition, the voting behavior of women in legislative institutions supports the conclusion that they are increasingly more similar. Frankovic (1977) finds that women in Congress were increasingly more similar in their voting patterns. This behavior has policy making ramifications as Leader (1977) finds that women are more likely to initiate proposals in traditional women's areas, and Saint Germain $(1989,965)$ finds that women are not only more likely to propose legislation that is consistent with the feminist agenda, but they are also more likely to pass it.

Although there may be similarities in the behavior of women legislators, the evidence does not suggest that there is a typical woman legislator. Significant variations across institutional settings exist; therefore, although many women policy makers may agree on broadly defined policy areas, their policy preferences may be shaped by the same variables that shape male legislators: their district, their institutional clout and their individual characteristics. These factors are all discussed in the literature, which addresses the institutional role of women in policy-making institutions.

The literature on the institutional factors influencing women legislators is extensive and suggests that variation in policy preferences and legislative activity is to be expected. As is the case with virtually all legislators, their policy making is determined by their relative positions within the institution. If a representative is a part of a clear majority block, his or her approach to legislation is quite different than that of minority members who must rely on others to pass their agenda. One of the most important variables in this area is the size of the women's delegation. In proposing and passing policies, the size of the delegation is critically important, particularly when the women's delegation is extremely small (Mezey 1978b; Lilie, Handberg and Lowery 1982). Not only does size affect the number of additional votes one must line up to pass legislation, but it also is a reflection of the overall clout of the delegation. This clout not only impacts legislative votes, but it may also impact another critical part of the legislative process, committee assignments. If there is an area where women legislators face severe institutional problems, it is in the area of committee assignments. Specifically, the perception that women are more interested in traditional women's issues results in women being assigned to health and welfare committees as opposed to finance and influence committees. Most legislators were not displeased with being placed on those committees because of their interest in traditional women's issues, but those who did have interest in finance and fiscal policy 
felt the system worked against placement on such committees (Diamond 1977, 89-90).

\section{Methods}

In order to analyze the roles of sex and party in influencing the membership's policy preferences, interviews and surveys were conducted with members of the 71st session of the Texas House of Representatives during January and February 1990 (the first called session). Because this survey occurred during a special session, the members faced a set agenda when it began. ${ }^{4}$ Any member who failed to return the survey was contacted and, if possible, interviewed in person in order to supplement the data set. In the end, 92 of the 149 House members responded; 31 of those members were personally interviewed. ${ }^{5}$ Of the 11 Democratic women in the Texas House, only one refused to participate while all 5 Republican women responded. Eleven of the women were interviewed. Fifty-seven respondents were Democrats and 35 were Republicans. Members were asked to give their opinions on various approaches to the four most pressing items on the session's agenda: education, judicial selection, workers' compensation insurance reform and abortion. Because these surveys were conducted at the beginning of the session, they provide what is arguably a true reflection of their views without the distorting effects of "log rolling."

The first topic members were asked about was educational finance reform. In June 1989, the Texas Supreme Court declared the Texas system of school finance unconstitutional and ordered the legislature to reform it. The legislature eventually produced a plan which increased some selected taxes, but was held unconstitutional within the year. The second topic was reforming the Texas system of judicial selection, which mandated countywide elections for state district judges in counties with multiple judges. A federal district court had ruled this plan unconstitutional and ordered the legislature to reform the system. Workers' compensation insurance reform was the third issue members were asked about. At the time of the survey, the legislature was finishing work on a reform plan that dominated the agenda during the 71st regular session and two subsequent special sessions and would be declared unconstitutional in 1991. Finally, members were asked about their positions on abortion. The U.S. Supreme Court's decision in Webster v. Reproductive Services galvanized both sides of the abortion controversy, prompting both to suggest legislative action. Because abortion restrictions remain the law in the absence of Roe $v$. Wade, a reversal of this ruling would effectively make Texas an anti-abortion state. 
The members were given lists of statements about each of the four problem areas, including potential reforms, and asked to indicate which of the 27 statements or reforms they agreed with. Because each statement and reform were not necessarily related, scales were not seen as a viable alternative. Support for each statement is therefore treated as unique. The consequence of this action is that 27 models are presented with support for each statement treated as the dependent variable. These responses serve to create dichotomous dependent variables with support for the statement coded 1 and opposition 0.

In order to assess the relative influence of sex and party on support for the statements, four independent variables are employed. Three of the four independent variables are dichotomous dummy variables with women and Democrats coded as 1 , while men and Republicans are coded as 0 . Because determining regional boundaries and relating them to legislative districts is a difficult proposition in Texas, accounting for regional variations has proven difficult. Observers of the Texas House have often found that splits between urban and rural representatives are more common and as a result, a dummy variable is created that isolates the delegations from the state's three largest urban areas: the Dallas-Fort Worth metroplex, Harris County (Houston) and Bexar County (San Antonio). The last variable included in the model is legislative tenure and it ranges from 0 to 24 . The central objective of the research is to measure the relative importance of party and gender, but the urban dummy variable and tenure provide a contrast for the relative importance of party and sex. Given the dichotomous dependent variable, logit models are run for each statement with four explanatory independent variables. ${ }^{6}$

\section{The Analysis}

Given the structural characteristics of the Texas House, one might expect the influence of party to be minimal in a legislature with minimal partisan influences. Given the recent anecdotal evidence, however, party may play a role on particular issues. In these sets of issues, it seems plausible that party affiliation may be an important predictor of the legislator's policy preferences on educational finance reform and on workers' compensation insurance reform, where business interests are closely linked to the G.O.P. The role of the legislator's sex is unclear, given the contradictions in the literature, but there is some reason to believe that sex will be important in the areas of education and abortion, where women have been shown to have particular interest and expertise. The results of this analysis are reported in Tables 1-4. Each policy area is isolated. 
Although some of the literature suggests that women are inclined to share a common interest with regard to issues such as education, there is no evidence that this interest translated into similar policy preferences in Texas. Even though the 71st Texas Legislature had faced court-ordered reform of the educational finance system, no consensus of opinion existed at the time of the survey. In Texas, as the state tries to address the funding imbalances that result when local districts are responsible for significant portions of the funding, education is seen as both a social issue and a fiscal issue. As Table 1 indicates, on these proposed education reforms, being a woman is never significant in explaining member support for the court's role or the specific solutions. The data here suggest that while women may tend to share interest

\section{Table 1. Influence of Sex, Party, Urban Districts, and Tenure on Legislative Policy Preferences Related to Education Reform}

\begin{tabular}{|c|c|c|c|c|c|}
\hline \multirow[b]{2}{*}{ Agreement With Statement } & \multicolumn{5}{|c|}{ Coefficient (STD Error) } \\
\hline & Intercept & Sex & Party & Urban & Tenure \\
\hline $\begin{array}{l}\text { 1. The courts have the right to } \\
\text { mandate state education policy }\end{array}$ & $\begin{array}{l}-3.00 \\
(.91)^{* *}\end{array}$ & $\begin{array}{l}2.11 \\
(.98)^{*}\end{array}$ & $\begin{array}{l}4.10 \\
(.87)^{* *}\end{array}$ & $\begin{array}{l}.45 \\
(.63)\end{array}$ & $\begin{array}{l}-.06 \\
(.05)\end{array}$ \\
\hline $\begin{array}{l}\text { 2. The ruling that the Texas system } \\
\text { was unconstitutional was correct }\end{array}$ & $\begin{array}{l}-2.88 \\
(.90)^{* *}\end{array}$ & $\begin{array}{l}1.17 \\
(.83)\end{array}$ & $\begin{array}{l}4.34 \\
(.87)^{* *}\end{array}$ & $\begin{array}{l}1.38 \\
(.80)\end{array}$ & $\begin{array}{l}-.04 \\
(.05)\end{array}$ \\
\hline $\begin{array}{l}\text { 3. The State should redistribute } \\
\text { funds without increasing spending }\end{array}$ & $\begin{array}{l}.92 \\
(.56)\end{array}$ & $\begin{array}{l}-.75 \\
(.71)\end{array}$ & $\begin{array}{l}-2.40 \\
(.57) * *\end{array}$ & $\begin{array}{l}-.38 \\
(.53)\end{array}$ & $\begin{array}{l}.05 \\
(.04)\end{array}$ \\
\hline $\begin{array}{l}\text { 4. The state should fund education } \\
\text { by increasing the sales tax }\end{array}$ & $\begin{array}{r}-1.53 \\
(.67)^{*}\end{array}$ & $\begin{array}{r}-1.47 \\
(.89)\end{array}$ & $\begin{array}{l}3.02 \\
(.70)^{* *}\end{array}$ & $\begin{array}{l}.38 \\
(.57)\end{array}$ & $\begin{array}{l}-.14 \\
(.05)^{* *}\end{array}$ \\
\hline $\begin{array}{l}\text { 5. The state should fund education } \\
\text { by increasing "sin" taxes }\end{array}$ & $\begin{array}{l}-1.38 \\
(.59)^{*}\end{array}$ & $\begin{array}{l}.30 \\
(.66)\end{array}$ & $\begin{array}{l}2.04 \\
(.57)^{* *}\end{array}$ & $\begin{array}{l}.45 \\
(.51)\end{array}$ & $\begin{array}{l}-.08 \\
(.04)\end{array}$ \\
\hline $\begin{array}{l}\text { 6. The state should fund education } \\
\text { by instituting a lottery }\end{array}$ & $\begin{array}{l}-1.92 \\
(.60)^{* *}\end{array}$ & $\begin{array}{l}.40 \\
(.65)\end{array}$ & $\begin{array}{l}1.77 \\
(.54)^{* *}\end{array}$ & $\begin{array}{l}.48 \\
(.51)\end{array}$ & $\begin{array}{l}.04 \\
(.04)\end{array}$ \\
\hline $\begin{array}{l}\text { 7. The state should fund education } \\
\text { by increasing property taxes }\end{array}$ & $\begin{array}{l}-4.57 \\
(1.23)^{* *}\end{array}$ & $\begin{array}{l}-.06 \\
(.89)\end{array}$ & $\begin{array}{l}2.92 \\
(1.11)^{* *}\end{array}$ & $\begin{array}{l}1.42 \\
(.67)^{*}\end{array}$ & $\begin{array}{l}-.01 \\
(.05)\end{array}$ \\
\hline $\begin{array}{l}\text { 8. The state should institute open } \\
\text { enrollment }\end{array}$ & $\begin{array}{l}.66 \\
(.54)\end{array}$ & $\begin{aligned}-2.37 \\
(.95)^{*}\end{aligned}$ & $\begin{array}{l}-1.99 \\
(.56)^{* *}\end{array}$ & $\begin{array}{l}.98 \\
(.53)\end{array}$ & $\begin{array}{l}.01 \\
(.04)\end{array}$ \\
\hline $\begin{array}{l}\text { 9. The state should fund education } \\
\text { by instituting an income tax }\end{array}$ & $\begin{array}{l}-4.24 \\
(1.18)^{* *}\end{array}$ & $\begin{array}{l}.89 \\
(.79)\end{array}$ & $\begin{array}{l}3.81 \\
(1.10)^{* *}\end{array}$ & $\begin{array}{l}.31 \\
(.60)\end{array}$ & $\begin{array}{l}.04 \\
(.04)\end{array}$ \\
\hline $\begin{array}{l}* \text { significance at } .05 \text { level } \\
* * \text { significance at } .01 \text { level }\end{array}$ & & & & & \\
\hline
\end{tabular}




\section{Table 2. Influence of Sex, Party, Urban Districts, and Tenure on Legislative Policy Preferences Related to Judicial Reform}

\begin{tabular}{|c|c|c|c|c|c|}
\hline \multirow[b]{2}{*}{ Agreement With Statement } & \multicolumn{5}{|c|}{ Coefficient (STD Error) } \\
\hline & Intercept & Sex & Party & Urban & Tenure \\
\hline $\begin{array}{l}\text { 1. The courts have right to mandate } \\
\text { type of judicial selection in Texas }\end{array}$ & $\begin{aligned}-3.22 \\
(.89) * *\end{aligned}$ & $\begin{array}{l}1.39 \\
(.81)\end{array}$ & $\begin{array}{l}3.95 \\
(.82)^{* *}\end{array}$ & $\begin{array}{l}.91 \\
(.65)\end{array}$ & $\begin{array}{l}-.04 \\
(.04)\end{array}$ \\
\hline $\begin{array}{l}\text { 2. The court ruling against county- } \\
\text { wide judicial elections is correct }\end{array}$ & $\begin{array}{l}-4.83 \\
(1.31)^{* *}\end{array}$ & $\begin{array}{l}3.12 \\
(1.19)^{* *}\end{array}$ & $\begin{array}{l}5.39 \\
(1.25)^{* *}\end{array}$ & $\begin{array}{l}1.77 \\
(.83)^{*}\end{array}$ & $\begin{array}{l}-.04 \\
(.05)\end{array}$ \\
\hline $\begin{array}{l}\text { 3. The state should institute merit } \\
\text { selection }\end{array}$ & $\begin{array}{l}.05 \\
(.54)\end{array}$ & $\begin{array}{l}-1.19 \\
(1.09)\end{array}$ & $\begin{array}{r}-1.23 \\
(.61)^{*}\end{array}$ & $\begin{array}{r}-1.47 \\
(.61)^{*}\end{array}$ & $\begin{array}{l}.01 \\
(.05)\end{array}$ \\
\hline $\begin{array}{l}\text { 4. The state should hold partisan } \\
\text { sub-county elections }\end{array}$ & $\begin{array}{l}-2.31 \\
(.69)^{* *}\end{array}$ & $\begin{array}{l}-.26 \\
(.68)\end{array}$ & $\begin{array}{l}2.58 \\
(.63) * *\end{array}$ & $\begin{array}{l}1.20 \\
(.58)^{*}\end{array}$ & $\begin{array}{l}-.02 \\
(.04)\end{array}$ \\
\hline $\begin{array}{l}\text { 5. The state should hold non-partisan } \\
\text { sub-county elections }\end{array}$ & $\begin{array}{l}.22 \\
(.55)\end{array}$ & $\begin{array}{l}.62 \\
(.71)\end{array}$ & $\begin{array}{l}-.16 \\
(.54)\end{array}$ & $\begin{array}{l}-.86 \\
(.55)\end{array}$ & $\begin{array}{l}-.12 \\
(.05)^{*}\end{array}$ \\
\hline $\begin{array}{l}\text { 6. The state should let the courts } \\
\text { handle it }\end{array}$ & $\begin{array}{l}-3.51 \\
(1.46)^{*}\end{array}$ & $\begin{array}{c}2.32 \\
(1.40)\end{array}$ & $\begin{array}{c}-8.92 \\
(24.50)\end{array}$ & $\begin{array}{c}.00 \\
(1.46)\end{array}$ & $\begin{array}{l}.12 \\
(.15)\end{array}$ \\
\hline $\begin{array}{l}* \text { significance at } .05 \text { level } \\
* *_{\text {significance at } .01 \text { level }}\end{array}$ & & & & & \\
\hline
\end{tabular}

in topics, it does not mean that their policy preferences will be different from men's. Interestingly, in spite of the low levels of partisanship in the Texas House, party influence explains significantly more than gender. This may be a function of the emerging partisanship on tax and spend issues, as Republicans often treat education as a tax issue. Neither the urban variable nor tenure was particularly helpful in explaining policy preferences in the area of education reform; each correlated in a statistically significant relation on only one of the nine statements.

In the second policy area considered, judicial selection reform, one should not expect a significant relationship for either sex or party. Although women legislators are often stereotyped as unconcerned with "non-people" issues like judicial reform, the issue was prominent in the 71st Texas House as a result of a federal court ruling that found that county-wide elections of state district judges discriminated against minorities. On this issue, some evidence of partisanship was again present, as Republicans in Dallas County feared losing district judges under the proposed plans. The issue of judicial selection reform was not new to Texas. The former Chief Justice of the Texas Supreme Court, John Hill (a Democrat), and the current Chief Justice 
Table 3. Influence of Sex, Party, Urban Districts, and Tenure on Legislative Policy Preferences Related to Workers' Compensation Insurance Reform

\begin{tabular}{|c|c|c|c|c|c|}
\hline \multirow[b]{2}{*}{ Agreement With Statement } & \multicolumn{5}{|c|}{ Coefficient (STD Error) } \\
\hline & Intercept & Sex & Party & Urban & Tenure \\
\hline $\begin{array}{l}\text { 1. The state should mandate payments } \\
\text { on actual lost wages plus the AMA } \\
\text { rating }\end{array}$ & $\begin{array}{l}3.09 \\
(.80)^{* *}\end{array}$ & $\begin{array}{r}-1.56 \\
(.81)\end{array}$ & $\begin{array}{l}-3.04 \\
(.73)^{* *}\end{array}$ & $\begin{aligned}-1.58 \\
(.68)^{*}\end{aligned}$ & $\begin{array}{l}-.02 \\
(.04)\end{array}$ \\
\hline $\begin{array}{l}\text { 2. State should mandate payments } \\
\text { based on lost wages plus lost wage } \\
\text { capacity }\end{array}$ & $\begin{array}{l}-3.83 \\
(1.19) * *\end{array}$ & $\begin{array}{l}1.29 \\
(.91)\end{array}$ & $\begin{array}{l}4.48 \\
(1.14)^{* *}\end{array}$ & $\begin{array}{l}.39 \\
(.63)\end{array}$ & $\begin{array}{l}-.06 \\
(.05)\end{array}$ \\
\hline $\begin{array}{l}\text { 3. The state should allow for dispute } \\
\text { resolution prior to trials }\end{array}$ & $\begin{array}{l}3.42 \\
(.86)^{* *}\end{array}$ & $\begin{array}{r}-1.41 \\
(.67)^{*}\end{array}$ & $\begin{array}{l}-1.85 \\
(.71)^{* *}\end{array}$ & $\begin{array}{r}-1.24 \\
(.61)^{*}\end{array}$ & $\begin{array}{l}-.06 \\
(.05)\end{array}$ \\
\hline $\begin{array}{l}\text { 4. The state should preserve the right } \\
\text { to jury trials }\end{array}$ & $\begin{array}{l}-2.45 \\
(.84)^{* *}\end{array}$ & $\begin{array}{l}.00 \\
(.83)\end{array}$ & $\begin{array}{l}4.35 \\
(.85)^{* *}\end{array}$ & $\begin{array}{l}1.34 \\
(.81)\end{array}$ & $\begin{array}{l}-.03 \\
(.05)\end{array}$ \\
\hline $\begin{array}{l}\text { 5. The state should allow companies to } \\
\text { self-insure }\end{array}$ & $\begin{array}{l}3.37 \\
(.82) * *\end{array}$ & $\begin{array}{l}-.64 \\
(.69)\end{array}$ & $\begin{array}{l}-2.34 \\
(.72)^{* *}\end{array}$ & $\begin{array}{l}-.82 \\
(.57)\end{array}$ & $\begin{array}{l}-.03 \\
(.04)\end{array}$ \\
\hline $\begin{array}{l}\text { 6. The state should require businesses } \\
\text { to upgrade safety standards }\end{array}$ & $\begin{array}{l}.72 \\
(.56)\end{array}$ & $\begin{array}{l}-.33 \\
(.75)\end{array}$ & $\begin{array}{l}1.13 \\
(.60)\end{array}$ & $\begin{array}{l}.24 \\
(.57)\end{array}$ & $\begin{array}{l}.00 \\
(.05)\end{array}$ \\
\hline
\end{tabular}

Tom Phillips (a Republican), were both crusading for merit selection of judges. The federal court ordered the legislature to devise a new method of judicial selection, and members were asked to express their support for the court's actions and respond to proposed solutions. The results of these logit models on judicial reform are seen in Table 2.

As judicial reform is not at the core of the feminist agenda or a traditional women's issue, being a woman is significant in explaining support for only one of the six statements. In contrast, party is more important again in four of the six cases. Interestingly, although tenure was statistically significant on only statement, the urban variable was significant on three of the six. This is not all that surprising, as the case dealt only with the state's nine most populous counties. Although these results are not as surprising as those on education given the literature on people issues, the policy preferences of women legislators are not significantly different from their male colleagues. 


\section{Table 4. Influence of Sex, Party, Urban Districts, and Tenure on Legislative Policy Preferences Related to Abortion}

\begin{tabular}{lccccc}
\hline & \multicolumn{5}{c}{ Coefficient $($ STD Error) } \\
Agreement With Statement & Intercept & Sex & Party & Urban & Tenure \\
\hline 1. The state should ban all abortions & -1.20 & .50 & -1.94 & .30 & -.11 \\
& $(.85)$ & $(1.26)$ & $(1.15)$ & $(.87)$ & $(.11)$ \\
2. The state should allow abortions & .50 & -2.05 & -1.15 & -1.53 & .09 \\
only to save a mother's life & $(.55)$ & $(1.12)$ & $(.58)^{*}$ & $(.56)^{* *}$ & $(.05)$ \\
3. The state should allow abortions & .76 & -2.26 & -.97 & -1.54 & .07 \\
in cases of rape and incest & $(.56)$ & $(1.11)^{*}$ & $(.57)$ & $(.55)^{* *}$ & $(.05)$ \\
& -1.03 & .18 & -.63 & -.53 & .08 \\
4. The state should only allow & $(.55)$ & $(.77)$ & $(.57)$ & $(.54)$ & $(.05)$ \\
abortions in the first trimester & -4.48 & 3.03 & 4.07 & 2.17 & -.15 \\
$\begin{array}{l}\text { 5. The state should allow unrestricted } \\
\text { access to abortions }\end{array}$ & $(1.27)^{* *}(1.02)^{* *}(1.16)^{* *}$ & $(2.17)^{* *}$ & $(.07)^{*}$ \\
6. The state should not restrict & -.18 & .11 & -.60 & -.07 & .01 \\
or fund abortions & $(.50)$ & $(.70)$ & $(.51)$ & $(.49)$ & $(.04)$ \\
* significance at .05 level & & & & & \\
**significance at .01 level & & & & & \\
\hline
\end{tabular}

As in the case of judicial reform, one would not necessarily expect a legislator's sex to explain much in the way of support for various workers' compensation reform proposals. The rising costs of workers' compensation insurance were supposedly forcing many companies to cease offering these policies and/or cease doing business in Texas. The effects of sex and party in explaining the policy preferences in this area are presented in Table 3. A familiar pattern is repeated here, as party explains support for five of the six proposed reforms, with high statistical significance in every case. Again, this may be a function of the issue; the Republicans were crusading heavily on behalf of the business community in the state, while the Democrats were more inclined to champion the cause of workers, labor and the powerful Texas Trial Lawyers Association. In contrast, being a woman is significant in only one model (at the .05 level). In fact, sex is less important than coming from an urban district on these policy statements; the urban variable is related in a statistically significant way in only two of the models. Overall, the pattern of sex being less significant in explaining positions is repeated again. 
The most obvious "woman's issue" facing the legislature in the 71st session was abortion reform. The Webster decision opened the door for state legislatures to change their laws and further restrict abortion opportunities. The survey asked the members to respond to six proposals that were being discussed. On this issue, the gender variable is significant in explaining support for two reforms, while party is also significant in explaining support for two. These results are seen in Table 4 . The logit models show that being a woman is no more relevant on questions of abortion than on any other issue area explored. Party, so important in the other three areas, is related with statistical significance on only two reforms: allowing abortions only to save a mother's life and supporting unrestricted access. The gender variable is as significant as party on the question of unrestricted access and significant at the .05 level on the question of allowing abortions in the case of rape and incest. In what may well reflect the dominant cleavage in the state on this issue, the urban variable was related and statistically significant on three of the six statements. Urban legislators were more likely to favor unrestricted access, and were not in support of the more restrictive alternatives that would allow for abortions only when the mothers life was in danger or in cases of rape and incest.

\section{Conclusions}

The four policy areas studied in this analysis were driven by the legislative agenda of the special session. As a result, they may not be reflective of all positions taken in the Texas Legislature. It should be noted at the outset that the small number of women in the House and the distribution of 10 Democratic women to 5 Republican women may limit the robustness of these conclusions. Nevertheless, these results present opportunities for replication in other settings where such limitations may not exist. This analysis offers three preliminary findings that may increase the understanding of the relative importance of gender and party in the Texas House of Representatives. First, although Texas may lack the structural forces that make party affiliation an important predictor of legislative positions, this analysis suggests that party can be and apparently is an important force in influencing legislative policy preferences. In this example, legislative policy positions in three of the four policy areas were influenced to a significant degree by party affiliation.

Second, in this setting, gender is of less importance in every case, including education and abortion. This finding, albeit on a relatively small cross-section of the membership, is completely inconsistent with the expectations driven from the literature on women in legislative institutions. Finally, 
the changing demographics of the state may have created yet another important cleavage in which the most populous counties in the state are pitted against the less populated areas. This analysis certainly found evidence of this fact in the policy areas of judicial reform and abortion. Because these results address only the relative importance of these four factors in four selected policy areas in only one state, further research is in order. From this analysis, however, it appears the importance of party affiliation in the Texas House is increasing and that the role of gender in determining policy preferences may be greatly exaggerated, at least as it applies to Texas.

\section{NOTES}

${ }^{1}$ In Speaker Clayton's four sessions, Republican chairs grew in number and percent. In $1975,10 \%$ of the Republican House members were chairmen. In 1981 this representation had grown to $35 \%$. Under Speaker Lewis in $1983,23.6 \%$ of the Republican delegation held chairmanships and today, $14.2 \%$ of the 56 Republicans are chairmen.

${ }^{2}$ In the 71 st Texas House, the Republicans numbered 60 of the 150 member delegation. They were also appointed to chair 9 of the 36 standing committees and held a majority of the membership on some committees, including the important Business and Commerce Committee, which dealt with workers' compensation insurance reform.

${ }^{3}$ In the Texas House, the traditional influence committees of Ways and Means, Appropriations and Calendars, the latter of which is the gatekeeper committee, are joined by State Affairs. State Affairs has a virtually limitless jurisdiction over any problem related to the state.

${ }^{4}$ Under the Texas Constitution, the legislature can meet beyond the constitutionally prescribed 140 days every other year only if the Governor calls it into special session. These special sessions have agendas that are fixed by the Governor. Members cannot add items to the agenda, and can only act on those issues that the Governor has placed on the agenda.

${ }^{5}$ There were no significant statistical differences in response between members who were interviewed and members who returned the questionnaire by mail.

${ }^{6}$ Given the sample size in the survey, logit analysis is more prudent in that it more clearly isolates the effects of the independent variables. While some might argue that the presence of 15 women as opposed to 57 Democrats will skew the results, a careful reading of the results, which compares the standard errors and coefficient scores, demonstrates the exact opposite to be the case. While the standard errors for gender are usually slightly larger than for party, the difference is clearly a function of the coefficients which is a result of the higher percentages of agreement among Democrats as opposed to women. 


\section{REFERENCES}

Becker, Robin A. 1989. Explaining Sex Roles of Women State Legislators in the MidAtlantic Region. Presented at the Midwest Political Science Association. Chicago, 1989.

Bullock, Charles S. and David W. Brady. 1985. Party, Constituency and Roll Call Voting in the U.S. Senate. In Glenn R. Parker, ed., Studies of Congress. Washington, D.C.: CQ Press.

Carroll, Susan J. 1985. Women as Candidates in American Politics. Bloomington: Indiana University Press.

Dallas Morning News, April 4, 1993, A1.

Darcy, Robert, Susan Welch and Janet Clark. 1984. Women in the Oklahoma Political System; State Legislative Elections. Social Science Journal 21:67-68. 1987. Women, Elections and Representation. New York: Longman.

Diamond, Irene. 1977. Sex Roles in the State House. New Haven: Yale University Press. Francis, Wayne L. 1985. Leadership, Party Caucuses, and Committees in U.S. State Legislatures. Legislative Studies Quarterly 10:243-288.

Francis, Wayne L. and James W. Riddlesperger. 1982. U.S. State Legislative Committees: Structure, Procedural Efficiency and Party Control. Legislative Studies Quarterly 7:453-471.

Frankovic, Kathleen. 1977. Sex and Voting in the U.S. House of Representatives: 19611975. American Politics Quarterly 5:315-30.

Guerrero, Lena. 1990. Presentation. In Harriet D. Romo, ed., Latinos and Blacks in the Cities: Policies for the 1990's. Austin: LBJ School of Public Affairs.

Hamm, Keith E. and Gary Moncrief. 1982. Effects of Structural Change in Legislative Committee Systems on their Performance in U.S. States. Legislative Studies Quarterly 3:383-399.

Jewell, Malcolm E. and Samuel C. Patterson. 1977. The Legislative Process in the United States. 3rd ed.; New York: Random House.

Jewell, Malcolm E. and David Olson. 1988. Political Parties and Elections in American States. Chicago: Dorsey Press.

Leader, Shelah G. 1977. The Policy Impact of Elected Women Officials. In Louis Maisel and Joseph Cooper, eds., The Impact of the Electoral Process. Beverly Hills: SAGE.

Lilie, Joyce R., Roger Handberg, Jr., and Wanda Lowery. 1982. Women State Legislators and the ERA. Women and Politics 2:23-38.

Main, Elanor C., et al. 1984. Different Perspectives: Southern State Legislators' Attitudes About Women in Politics. Social Science Journal 21:21-28.

Mandel, Ruth. 1981. In The Running: The New Woman Candidate. New York: Tickner and Fields.

McNeely, Dave. 1989. Last of the Good Old Boys. State Legislatures, (November/ December):27-29.

Mezey, Susan Gluck. 1978a. Women and Representation: The Case of Hawaii. The Journal of Politics 40:369-385.

. 1978b. Support For Women's Rights Policy: An Analysis of Local Politicians. American Politics Quarterly 6(4):485-497. 
Rosenthal, Alan. 1981. Legislative Life: People, Process and Performance in the States. New York: Harper and Row.

Rule, Wilma. 1981. Why Women Don't Run: The Critical Contextual Factors in Women's Legislative Recruitment. Western Political Quarterly 34:60-77.

.1990. Why Women are State Legislators: A Research Note. Western Political Quarterly. 43:437-48.

Saint-Germain, Michelle A. 1989. Does Their Difference Make a Difference? The Impact of Women on Public Policy in the Arizona Legislature. Social Science Quarterly 70:956-68.

Sapiro, Virginia. 1981. When Are Interests Interesting? The Problem of Political Representation of Women. American Political Science Review 75:701-16.

Shelley, Mack C. 1983. The Permanent Majority: The Conservative Coalition in The United States Congress. University, AL: University of Alabama Press.

Thielemann, Gregory S. and Clark D. Thomas. 1990. Myth and Reality: The Conservative Nature of the East Texas Delegation to the Texas House of Representatives. Texas Journal of Political Studies 13(1):46-64.

Werner, Emmy E. 1968. Women in State Legislatures. Western Political Quarterly 21: 40-50. 